\title{
A Transition of Internationalisms: Britain, the United States, and the Formation of the United Nations Information Organization during World War II
}

\author{
Giles Scott-Smith
}

HCM 7: 1-23

DOI: $10.18352 / \mathrm{hcm} .549$

\begin{abstract}
The United Nations Information Office (UNIO), dating from I942, holds the distinction of being both the first international agency of the embryonic UN network and the first to hold the United Nations label. Run from I 942 to I 945 from two offices in New York and London, these two were merged at the end of World War II to form the UN Information Organisation, and subsequently transformed into the Department of Public Information run from UN headquarters in New York. This article adds to the history of the UN by exploring the origins and development of the UNIO during I940-4I, when it was a British-led propaganda operation to gather US support for the allied war effort. It also examines the UNIO from the viewpoint of the power transition from Britain to the United States that took place during the war, and how this reflected a transition of internationalisms: from the British view of world order through benevolent imperialism to the American view of a progressive campaign for global development and human rights.
\end{abstract}

Keywords: empire, internationalism, public diplomacy, public opinion, United Nations 


\section{Introduction}

This article situates the emergence of the United Nations during World War II in the context of competing interests in international organization put forward by Britain and the United States. It does so by examining the origins and development of the United Nations Information Office (UNIO), at its creation in 1942 the first international agency of the embryonic UN network and the first to hold the United Nations label.

It is not a coincidence that the state-led provision of information for the purpose of deliberately persuading foreign publics (generally termed public diplomacy) was the first field to receive attention when creating the UN. The adjudged failure of the League of Nations to maintain peace made it obvious that a new venture in international organization would require convincing a sceptical public of its goals, methods and chances of success. Yet this first required achieving consensus among the allied powers as to what the message should be, and what kind of an organization should deliver it.

In contrast to assumptions of Anglo-American unity for the allied cause, the formation of the UNIO is approached here in the context of the power transition from Britain to the United States during the war. The initial phase, from I940-4I, demonstrates how Britain employed an information strategy to persuade a neutral United States to support the anti-Nazi war effort and ultimately join the Allied cause. Once the United States entered the war, it gradually took control of the wartime information campaign under the name of the United Nations. The United States aimed to refashion the nascent UN's public diplomacy campaign away from its original British blueprint, which did not serve its purposes as a rising world power taking on broader responsibilities. The story of UN public diplomacy during World War II is therefore also related to the international history of public diplomacy, with the US as both protagonist and recipient. ${ }^{I}$ How did this power transition in the field of public diplomacy take place, and how did it also reflect a transition in versions of internationalism, from British to American?

\section{British and American Internationalisms}

The transnational turn in diplomatic history has led to a greater focus on manifestations of internationalism, particularly in the first half of 
the twentieth century. ${ }^{2}$ Much of this scholarship has given attention to the many initiatives to propagate interstate cooperation in specific policy fields, particularly through newly-created international organizations, with the League of Nations as the central point of these emerging networks of global governance. ${ }^{3}$ Historians have tracked how these networks evolved, transformed and adapted into the structures of the United Nations Organization in the middle of the twentieth century, looking beyond I945 as the formative year for its arrival. ${ }^{4}$ Much of this history has been written from a progressive liberal perspective, taking the view that internationalism was a force for good closely related to imprinting norms of good governance, providing better services, responding to public opinion, instilling democratic ideals and ultimately transforming the system of states itself in a more peaceful direction. ${ }^{5}$ Twentieth-century internationalisms therefore expressed 'both an instrumental and a normative view of social and global unity'. ${ }^{6}$ As Glenda Sluga has noted:

The stimulant for this popular and intellectual interest in a new internationalism was not only the transnational spread of ideas and power of 'public opinion' that accompanied mass literacy, but also the constant threat of war and the evidence of atrocities in the name of nationalism. In the circumstances, internationalism seemed to many the most likely path to a 'permanent peace' and to the fulfilment of the democratic ambitions of men, women, and anticolonialists who had limited political representation in nation-states and empires. ${ }^{7}$

Most histories of the UN tend to pass over the UNIO. ${ }^{8}$ Stephen Schlesinger picks up the story of UN public diplomacy only in I944, and then in the form of the post-Dumbarton Oaks publicity blitz propagated by the US State Department. ${ }^{9}$ In-depth studies have been made on the mobilization of private groups that propagated an internationalist agenda within a still neutral United States, and particularly the role of Clark Eichelberger. ${ }^{10}$ On the UNIO itself, Dan Plesch has argued that it was an essential component of the wartime coalition that mobilized and defeated Nazi-fascist totalitarianism. Plesch argues convincingly that the wartime alliance was consistently presented to the world by the UNIO as an alliance of United Nations, which achieved a collective victory in the interests of a collectively organized peace. ${ }^{\text {II }}$ 
This article emphasizes the importance of the UNIO from the perspective of US-UK relations during World War II, in doing so questioning the assumptions of allied unity drawn by Plesch. It is useful in this context that Sandrine Kott has described the war as a contest between 'competing internationalisms': 'The first was based on liberal values and on freedom and led by a Euro-Atlantic alliance, the second was led by Nazi Germany and emphasised the hierarchy of races and nations and the third one embodied by the Soviet Union and promoting communist conceptions of economic and social equality. ${ }^{\text {'2 }}$ Within this contest, Kott emphasises 'the shift in the balance of power from Europe to North America' as both the location of secretariats and the focus of future planning began to revolve around Washington's worldview. ${ }^{13}$ But within the Euro-Atlantic alliance there was also a struggle over postwar conceptions of world order. In this context, the article takes up the challenge of Glenda Sluga and Patricia Clavin to 'encourage the incorporation - and historical clarification - of conflicting and contested narratives of the international as a realm of politics'. ${ }^{14}$

Approaching the UNIO from the perspective of great power influence shifts attention towards the Anglo-American debate on post-war organization that took place behind the public presentation of a united allied cause. Britain's foremost aim was to bring the United States into the war on the side of freedom, while simultaneously heavily circumscribing that same freedom by dampening expectations of a rapid withdrawal of imperial control from around the world. British internationalism was therefore still built on the assumption of an ongoing world role built on political tutelage, racial hierarchy and a continuation of its pre-war imperial civilizing mission. ${ }^{15}$ Britain had succeeded in shaping the League according to its imperial needs by heavily influencing the course of post-war planning during I9I6-I8, particularly in the form of the League's mandate system. ${ }^{16}$

In contrast, American internationalism was framed more distinctly around a modernizing, anti-imperial narrative. President Roosevelt's Four Freedoms speech of 6 January I94 I had boldly outlined the ambition of the United States to aim for the deliverance of basic human rights on a global scale 'anywhere in the world' ${ }^{17}$ American officials understood that Churchill saw the war as another opportunity for claiming the merits of empire as a force for order and 'civilization', whereas in fact anti-colonial sentiments were fuelling support for the Axis powers 
across the Middle East and South and East Asia. ${ }^{18}$ The US would aim to position itself as the provider of public goods as part of its own, 'post-imperial' civilising mission. That this involved a transition from a British-led conception of the world to an American-led alternative was clear for everyone in the post-war planning field. Thus Stanford historian Harley Notter, closely involved in the State Department's wartime development of a cultural agenda and a public diplomacy apparatus to propagate it around the globe, saw 'the drift of history' in the transfer of hegemonic leadership from Britain to the United States. Once the US entered the war, the United Nations became a focal point for that transition. ${ }^{19}$

The relationship between internationalism and public opinion - that literate publics were both an influence behind and a party to internationalist mobilization, and a focus of attention for international organisations seeking to establish their legitimacy within a state system - has become a given. The League had functioned according to the simple principle that by providing the correct, factual information in a timely and well-distributed manner, public opinion could be enlightened and 'shaped' in the direction that was required, laying the basis for a transformation in international affairs. Eric Drummond, the first SecretaryGeneral of the League of Nations, summed up the approach:

The League's main force is publicity, in the sense of public discussion and public documents by which world opinion may judge the results. The League recognizes this. It opens its doors and makes information available [...] It neither interprets news nor, in the journalistic understanding of the term, transmits it. ${ }^{20}$

The UN's own public diplomacy campaign after World War II also adopted this facts-only approach, but during the war itself the stakes were higher because the new organisation needed to be established as a more effective venture than the defunct League. On the surface, the history of the UNIO covers the large-scale multinational investment in drafting and proselytizing a coherent, sustained message on victory and peace to the global public - what was the war being fought for, and how would the organization of the post-war world guarantee the realization of the allied goals and values. Meanwhile behind the scenes a contest between British and American views on international organisation took 
place, particularly concerning who would direct this new venture in multinational public diplomacy.

\section{The Creation of the Inter-Allied Information Committee}

The British propaganda campaign in the United States during World War II has been well covered elsewhere by Nicholas Cull and Susan Brewer. Cull covers in detail the build-up and execution of the wellorchestrated information operation between I939 and I94 I designed to oppose American isolationism and bring the United States into the war. ${ }^{21}$ Brewer builds on this by following the story through the rest of World War II in order to establish how British officials worked to 'sell' the notion of an Anglo-American 'special relationship'. The stakes were high: 'Without American assistance ... they could neither win the war nor establish a favorable peace.' ${ }^{22}$

The obstacles to achieving this were not only isolationist sentiments, but also the negative legacies of World War I. Less than twenty-five years before, Britain had waged a major campaign to persuade the United States to enter the war against Germany, with the result that many felt US interests (and lives) had been betrayed by a cabal of proimperial transatlantic financiers and arms dealers. ${ }^{23}$ Now faced with a similar situation, Britain had to find a way to once again influence American opinion and yet avoid accusations of underhand manipulation. The British Council, despite being founded to respond to Nazi and fascist world-views, was excluded from operating in the United States during the early years of the war. ${ }^{24}$ A two-pronged strategy was the result: a 'no propaganda' information policy run by the Foreign Office and the Ministry of Information, and a covert campaign waged through British Security Coordination (BSC), the clandestine outfit led by Canadian William Stephenson, against advocates of isolationism. Both strands of the strategy could draw on active support from a host of American internationalist lobbying organisations (the degree to which some of these were creations of British subterfuge or simply allied with the British cause is a continuing debate). ${ }^{25}$

The first step towards what would become the UNIO was taken in September I940 with the creation of the Inter-Allied Information Committee and its Information Center (IAIC) in New York in September 
I940. The brainchild of the British Ambassador, Lord Lothian, the IAIC provided a way forward that avoided both the 'neutral' approach of the existing propaganda outlets and the high-risk activities of the BSC, but which fitted neatly into the context that they had already set out. The IAIC was intended to coordinate the many voices of the anti-Nazi and anti-Japanese forces and, under British tutelage, act as a "clearing house' for the multiple information services. The Committee therefore provided an outlet for British-style internationalism, where imperial right was clothed in a broader coalition of anti-totalitarian forces to emphasize the crucial role of Britain as a force for moral good and global order.

Lothian was ambassador in Washington DC for just over a year (September I939 - December I940) before his untimely death on I2 December $1940 .{ }^{26} \mathrm{He}$ was determined to maintain Foreign Office control over information provision in the United States, located principally at the British Library of Information (BLI) in New York, despite the increasing demands of the Ministry of Information (MI), created in September 1939 for the purpose of producing 'national propaganda' to influence foreign opinion and maintain domestic morale. In March I940 the Foreign Office blocked the request of the MI's America Division head, Sir Frederick Whyte, to visit the United States for fear that this would arouse American suspicions. ${ }^{27}$ Instead, in February I940 Lothian requested that Michael Huxley be appointed as First Secretary to his embassy from the Foreign Office in order to 'ensure proper contact with the press', sort out the burgeoning FO/MI rivalry over control of the BLI, and streamline information channels in both the United States and Britain itself. ${ }^{28}$ Huxley had previously served at the embassy and in the FO's News Department, and was supportive of Lothian's wish to keep MI involvement at arm's length. But Huxley's role would soon take a new turn.

On Io April I940 Lothian cabled London that 'in the long view the only sound foundation for American policy is a shrewd sense of where America's own vital interests lie ... No American will be influenced in the least by any opinion we may express as to where American selfinterest lies ... It only makes them see red.' ${ }^{29}$ The problem was how to shift the outlet of propaganda away from Britain, while at the same time keeping British control over its direction. It required challenging the standpoints of American isolationists but in a different way to the 
high-risk escapades of Stephenson's BSC. ${ }^{30}$ It would have to appeal to the latent internationalism in US public opinion by illustrating that the war involved a collective effort for good, and did not represent the rescue of a handful of archaic empires shielded by an empty rhetoric of freedom. It needed to remain within the bounds of the stringent Foreign Agents Registration Act in the United States that was passed in I938, explicitly based on the World War I experience, with the purpose of preventing unattributed propaganda campaigns by foreign parties.

The answer lay in utilizing multilateralism. Already in early I940, FO officials discussed the possibility of using Czech and Polish organizations or 'neutral capitals' as outlets for anti-German propaganda. In April a meeting was held with Mr. Ostelius, manager of the Swedish American Line, who was willing to spread Allied 'discreet propaganda' among the Scandinavian communities in the United States. This was applauded, but the danger of it backfiring if exposed as a 'front' for British propaganda was all too evident. ${ }^{3 \mathrm{I}}$ The breakthrough came in June I940. Internationally, the fall of France had created an immediate problem regarding the French information services resident in New York. Domestically, a struggle for control of the information portfolio was being waged between the FO and the MI. The arrival of the forthright Alfred Duff Cooper as the new Minister of Information in May placed relations on a more difficult footing, as Cooper set about establishing an MI-controlled Office of Information in New York. This being in his backyard, at the end of June Lothian cabled a response:

Each of the Allies has hitherto been conducting publicity movement though loose collaboration has existed [...] Essential that we should maintain an Allied publicity front as the Germans are losing no time in exploiting AngloFrench differences and certain Americans are taking every opportunity for their own political reasons of decrying British ability to speak for the other Allies. Any loss of contact between the Allied groups in the United States would therefore place us at a grave disadvantage. Officials prepared to cooperate in the immediate formation of inter-Allied information committee in New York for publicity activities centre under British leadership to consider frequent and regular plans for collaboration against Nazi propaganda. ${ }^{32}$

Not receiving an immediate reply, Lothian followed up a week later by announcing the unilateral establishment of the proposed committee 
and centre under Huxley's leadership, in doing so bypassing Cooper's criticism of such Allied liaison as 'a mistake' and 'an obvious waste of time'. ${ }^{33}$ Lothian pressed ahead regardless, by mid-September claiming that 'a role of considerable importance is reserved for this organization', and a month later the FO was praising the IAIC as 'a high grade information bureau and centre for the discussion of the future aims of Europe.' The FO provided the lion's share of the budget with \$2000 a month, with other nations providing 'on a scale based on former contributions to League of Nations budget.' 34

Lothian's unilateral decision had effectively created the basis for what would become the United Nations Information Office. The first meeting of the IAIC took place on 24 September I940, chaired by Huxley and with Czech, Dutch, French and Norwegian representatives and Belgian and Luxembourg observers present. The meeting indicated its intention to focus on the European minority communities in the US and 'the danger to American interests of a totalitarian Europe, especially in view of the widespread Nazi propaganda tending to persuade Americans that the United States can maintain profitable economic relations with such a Europe.' Huxley had written to Secretary of State Cordell Hull on I6 September to inform him of the 'Advisory Committee' and that all representatives would register as requested under the Foreign Agents Assistance Acts of I938-39.35 The IAIC, an overt information platform, was also closely tied to BSC operations because contact with France Forever, the pro-de Gaulle publicity arm, was maintained, according to author Thomas Mahl, 'through BSC agent Sandy Griffith and Market Analysts Inc.' The IAIC was housed at 62 I Fifth Avenue, New York the same location, not coincidentally, as the BSC. ${ }^{36}$ Lothian's initiative therefore bridged the covert and overt information campaigns to ensure careful coordination.

The IAIC did meet resistance in the US government, notably in the form of the State Department's Assistant Secretary of State for Latin American Affairs, and distinct Anglophobe, Adolf Berle. ${ }^{37}$ In late I94I, immediately after the US entered the war, the State Department called for Americans to no longer serve on 'free movement' committees (exactly the committees targeted by the IAIC with its pro-war propaganda) in order to promote a united front of all citizens in the wartime situation. ${ }^{38}$ On 9 January I 942 Berle met with Sir Ronald Campbell and Sir Gerald Campbell of the British embassy to discuss the legality of 
IAIC operations. Berle stated that 'this country has never been happy about foreign propaganda inside its borders, and especially disliked foreign propaganda directed to its foreign language newspapers', which, he stated later, could 'simply Balkanize the United States'. A 'logical solution', now that the US had entered the war, would be the dissolution of the IAIC and its replacement by a State Department-coordinated press operation. ${ }^{39}$ Berle saw IAIC, not incorrectly, as a cover for British propaganda, and he was also opposed to the activities of BSC which, involving the gathering of intelligence and conducting covert operations within the US, were flagrantly in breach of the Foreign Agents Registration Act.

When an amended, strengthened version of the Act was passed and sent to Roosevelt for signature in February I942, pressure came for a presidential veto from Roosevelt's own Coordinator of Information, William Donovan, a close associate of BSC. Berle's opposition to the veto was ignored by Roosevelt, who backed Donovan and returned the legislation in the interests of 'a minimum of interference with the strengthening and perfecting of joint action' between wartime allies..$^{40} \mathrm{~A}$ watered-down version was duly passed by Roosevelt in April. Berle even learnt through the FBI of an apparent BSC attempt to smear him in the media and so obtain his resignation. ${ }^{4 \mathrm{I}}$ But Donovan prevailed, Berle was overruled, and as a result British overt and covert campaigns, IAIC included, could continue. Berle was bitter on his defeat, and pressure on British covert activities would continue to come from both the State and Justice departments. ${ }^{42}$ Commenting on the poor war situation after the fall of Singapore, Berle wrote: "Gone is the ideal of the "English speaking world"; and on dead reckoning, the era of Anglo-American operation will be pretty short [...] Briefly, we must look for common denominators, which must take in Chinese, and Burmese, and Indians, and Malayans, and Javanese, and so forth, as well as white sahibs and plantation owners ... After all, these people had nothing to defend but their own exploitation.' ${ }^{43}$

\section{Power Transition: From IAIC to UNIO}

A document from the UN archives, dated January I943, identifies three basic stages of development of the IAIC and its transformation into the UNIO. The first involved the coordination of separate national 
efforts by the IAIC to increase the understanding of their cause. Thus from January I94I the monthly Inter-Allied Review was issued as 'a record of documents and statements regarding the fight of the Allies against aggression and for world freedom. ${ }^{44}$ Close partnerships were developed with US interventionist lobbies such as Clark Eichelberger's Committee to Defend America. ${ }^{45}$ The second stage saw the creation of an extensive reference library to provide information on the war effort to an increasingly involved American press and public. By late I94I, the IAIC was coordinating a complete media operation with press, broadcasting, editorial and documentary and film sub-committees.

The third stage was marked by the entry of the United States into the war and a subsequent demand 'for understanding of the common aims and objectives for which each and all were fighting.' In this period (I942-43) the IAIC morphed into the UNIO, and the emphasis shifted from winning the war to constructing the peace. This shift is probably the most marked difference between the British-led IAIC and the US-led UNIO, and signifies the way in which the IAIC-UNIO transition also marks a transition of internationalisms and associated world orders, from presumptions of continuing British imperial might to the more idealist, universalist American aspirations of Franklin Roosevelt's Four Freedoms. The IAIC was a way for Britain to bypass stringent US restrictions on propaganda by foreign powers, but once the US entered the war it had largely served its purpose.

It was only in July I942, following the formation of the Office of War Information (OWI) in June, that the United States itself became a member of the IAIC. The six-month wait following Pearl Harbour, the entry of the US into the war and Roosevelt's Declaration of United Nations was due to lack of agreement on which American body should take on the role of wartime propaganda. The State Department was necessarily excluded, the IAIC having clear US domestic implications. With the arrival of the OWI came also an American demand to change the name; this was 'a matter of considerable importance', as stated in the sixtyfirst IAIC meeting in November $1942 .{ }^{46}$ As a result, ten months after the Declaration of United Nations, the New York-based Information Center became the United Nations Information Office overseen by a UN Information Board (UNIB), and all signatories of the Declaration were invited to join. The first meeting of the UNIB - and the sixtythird and last of the IAIC - took place at the Rockefeller Center on I 
December 1942. By January I943 the Inter-Allied Review had become the United Nations Review, and from the same month the UNIO started issuing a series of supplements on War and Peace Aims, very much indicative of US post-war ambitions.

The transition from IAIC to UNIO looks relatively smooth on the surface, but what becomes apparent when examining the records is a transition from London to New York concerning the control of information provision. The name change was one overt aspect of this. The purpose of the apparatus was another. In preparation for the IAIC-UNIO transition, a policy document (reading more like a propaganda release) was prepared that spelled out some of the significant changes. With the entry of the US into the war,

The problem of trying to win the sympathy of the American public for the Allied cause ceased to be as important, but in its place there arose a demand for understanding of the aims and objectives for which each and all were fighting. The beginning of this change was recognized by the Committee when it decided to create a section for information on post-war reconstruction studies [...the] American people turned enthusiastically to the concept of 'United Nations'. It brought a new hope to those who saw the civilized world crumbling. As a result [...] it has been possible for the Board and Office to undertake new functions to meet American demands. ${ }^{47}$

The organizational apparatus also indicates a hidden rivalry. In late I94I the MI had created its own Inter-Allied Section in London as an equivalent to the New York-based IAIC. When the UNIO/UNIB apparatus was established in November-December I942, the MI kept the IAIC label for the London operation, in so doing maintaining a distinction between the US-led and British-led public diplomacy operations. On I November I 943 the MI finally disbanded its Inter-Allied Section and the IAIC became a multinational organization financed entirely by contributions from member governments, similar to its New York counterpart. It was only in May I 944 that the London-based operation was also renamed as the UNIO and fully integrated into the New York apparatus, and only in January I945 that the UN News Bulletin was issued in identical form from both offices. The British wartime propaganda operation was thus first multilateralized and then Americanized, but it had taken two and a half years. 
Why this convoluted transition? Firstly, there is the bureaucratic explanation. The MI had struggled to gain control of information operations in the United States from the Foreign Office, eventually succeeding with the formation of British Information Services in New York in I942. In these circumstances, it was logical that the Ministry would look to keep hold of its operations for as long as possible, making use of the worldwide scope of IAIC propaganda for promoting British interests well into I944. The question was who would control the senior positions on the UN Information Board, and how the New York and London offices would relate to each other. Leading this transition from the British-led wartime propaganda IAIC to a US-led body framed around the goals of the United Nations was the American Arthur Sweetser. A journalist with Associated Press, Sweetser's conviction that peace would only be secured by overcoming international rivalries had led him to become a part of Woodrow Wilson's entourage in Paris in I9I9, and from there a position in the League's Geneva Secretariat, eventually becoming head of its Public Information section. Sweetser was a crucial actor in bringing the League's technical apparatus to the United States in I940, and his expertise secured his appointment as deputy head of the OWI. From that position he was duly made chair of the newly-formed UNIO in I942, a logical step from his former League work. Sweetser saw this as a golden opportunity to "promote internationalism in the United States,' a second chance after the failure to secure US membership of the League..$^{4}$ Speaking in I945, Sweetser saw only continuity of the same mission: 'The United Nations will be in size, in scope, in personnel, in budget, and in cost a good many times the size of the League ... But even with that, the basic principle, as I am trying to emphasise, is really the same.' 49

At the time of OWI's admission to the IAIC and its metamorphosis into the UNIO in November-December I942, the division of authority was shared between a British secretary-general and an American (Sweetser) acting as chairman of the board. This division worked well up until the general effort to genuinely multilateralize the UN information apparatus in I944. A proposal was put forward to make the director of OWI an honorary chairman, and the acting chairman to be elected by secret ballot, for three months, without re-election. Sweetser, who was not party to this proposal, rejected it out of hand as a reduction of US control even when the office was based in New York. ${ }^{50}$ This episode 
illustrated, according to an observer at the British embassy, the "natural reluctance on the part of Americans to take part in any publicity venture that is not run by Americans on American lines.' ${ }^{51}$ But this was not all. US representatives were constrained by the need to obtain Senate approval for their involvement in a sensitive venture like the UNIO. Sensitivities towards foreign propaganda being conducted within the US continued to complicate congressional acceptance of pro-UN initiatives. ${ }^{52}$ This prevented the OWI from entering into an official agreement that would allow for US participation in the London-based IAIC. Constitutional issues therefore prevented the smooth cooperation between the New York and London information operations, and delayed the process of their formal merging until I $944-45$ when the UN apparatus was being formalized.

Following the Declaration of United Nations in January I942, fear of triggering resistance in the Senate to any new international agreements meant that President Roosevelt was very reticent to discuss UN planning publicly during the following three years. ${ }^{53}$ The room for manoeuvre for the UNIO was therefore from the beginning circumscribed by US national interest. Politically this had to be managed very carefully. US public opinion avidly picked up on the United Nations as a concept for winning the war and creating a better peace. The UNIO report 'Postwar Trends in the United States' from mid-I943 includes a survey of the American press that demonstrates widespread civilian and military support for the Four Freedoms and 'active, effective cooperation with other nations after the war, even if such cooperation takes the form of a world federation in which the United States would merge some of its sovereign rights.' ${ }^{54}$ The value of the UN concept as a 'psychological weapon' for propelling the war effort was clear, but there was also the danger that public demand for concrete results would outstrip political capabilities to reach agreement.

The relations between the UNIO and the agencies of the US government were therefore of special importance, to ensure full coordination of the information campaign in line with the Roosevelt administration's domestic political agenda. In September I942 a working agreement with the OWI was finalized which spelled this out. To meet congressional demands, the agreement included the demand that 'the policy and program of the Inter-Allied Information Center shall be consistent with the policy and the program of the Office of War Information.' 55 
Since technically the IAIC had to work according to unanimity, this same approach applied to all of its member states, yet the implication that the organization could no longer function without US approval was clear.

Differences in opinion on the message to be promoted also existed. An OWI pamphlet, The United Nations Fight for the Four Freedoms, was blocked from being distributed in India by the State Department because its call for equality effectively opposed British rule and could undermine the war effort. From an opposing angle, from 1942 the MI used the United Nations label as a way to counter Indian demands for British withdrawal, insisting instead that the collective interest lay with first winning the war and then determining the passage of decolonization..$^{56}$

This latent imperial impulse can be seen in the move in London to create an independent IAIC outside of the MI in November I943, as part of the effort to consolidate British influence through a multinational Commonwealth block of nations. Throughout that year a determined push was made for Dominion involvement 'as demonstrating the solidarity of the British Commonwealth and of the United Nations. ${ }^{57}$ Dominion membership was seen as a way to continue British influence in the emerging US-led information apparatus. The MI, which intended to generously fund the new UNIO, 'have all along been very anxious that the Dominions should be represented on this new organization through their high commissioners in London.' ${ }^{58}$ Canada, Australia, and South Africa complied, as did India (but not New Zealand). Yet these moves were also an indication that British involvement in the UNIO apparatus was waning. British policy in 1943-44 was in general focused on nurturing a strong sense of Commonwealth solidarity as a way to maintain importance in the approaching post-war international system. ${ }^{59}$ Yet the shape of the future UN organization was increasingly a US-led process, and British efforts to garner Dominion support was clearly a rearguard action to delay declining influence.

By the end of I944 the IAIC and the UNIO had collectively held more than one hundred sessions, with sub-committees covering films, exhibitions, radio, the press, women's' affairs, and postwar planning. The arrival of new UN agencies such as the UN Relief and Rehabilitation Administration and the Food and Agriculture 
Organisation necessitated the expansion of UNIO's task to show that the different elements of the UN system itself were working together. Differences of opinion among the Allies were nevertheless occasionally acknowledged in the publicity material. An early analysis by the Federal Communications Commission confirmed that 'solidarity' was the most appropriate keyword for the radio broadcasts of the allied nations, and particularly in terms of the relationship between Russia and the other allies. The report stated that "praise of Russia occurs with such frequency in the United Nations' broadcasts as to warrant specific mention as a recurring and important theme in itself.' Eurocentrism is also a distinct aspect of UNIO output. Disagreements primarily existed in relation to Australian, Chinese and Dutch East Indies criticism of the Pacific war being given secondary status in comparison with Europe and Britain's weak position in the region as a result. It was the BBC and not the UNIO that countered with details of the British war effort and a general aim to resist the potential appeal of fascist propaganda dividing the allies among themselves. ${ }^{60}$

Despite these underlying tensions, the central focus of the UNIO narrative, allied solidarity, was scrupulously maintained. A publicity document chronicling the evolution of the United Nations referred to seventy-four separate top-level meetings between June I94I and April I 945 covering the war effort and post-war planning. ${ }^{61}$ The pitch was solidly along the lines that victory was only achievable because of the cooperation initiated by the United Nations. The UN role in the war effort in Europe is described thus:

The coordinated military strategy of the United Nations that resulted in the great victorious campaigns of western and eastern Europe, was planned at Tehran and later at Yalta, by Marshal Stalin, Prime Minister Churchill and the late President Roosevelt. Acting on these plans, the Combined Chiefs of Staff set in motion the mighty forces that ultimately linked up the Allied armies' offensive in the west with that of the triumphant Red Army in the east. $^{62}$

This was backed up by visual imagery of a united front against Nazism, such as US and Soviet forces meeting at Torgau in I945. The image of great power cooperation would be continued, albeit with declining effectiveness, into the post-war years. 


\section{Conclusion}

The UN Information Office that was eventually formalized in January I945 was intended to tell 'the same story all around the world,' demonstrating the interdependence of US and Allied interests into the postwar future. ${ }^{63}$ The Office's remit for action was therefore anything that emphasized Allied unity, mutual aid and interests, and 'the importance of cooperation and joint action for winning not only the war, but also the peace. ${ }^{64}$ The official resolution provided for the 'formal constitution' of the UNIO, with offices in New York and Washington, D.C. - not London. ${ }^{65}$ To confirm the dominant position of the United States, the resolution declared that the Director of the Office of War Information would convene the first meeting of the UNIO's official representatives to determine its officers. The UNIO was subsequently transformed into the Department of Public Information run from UN headquarters in New York and given the responsibility for running the organization's public diplomacy campaigns. ${ }^{66}$

The standard line on UN origins rightly emphasizes the dominant US role in its formation, but this needs to be seen in the context of a transition from British to American views on world organization. By tracing the development of the UNIO through the lens of competing British and American internationalisms, the significance of this bureau in terms of the evolution of Anglo-American relations and their respective ideas of world order becomes clear. The IAIC in New York was created in September I940 due to a combination of national emergency (the fall of France) and bureaucratic rivalry (between Foreign Office and Ministry of Information). From I94I, when the MI created a London office, there was a New York/London duality in information provision that continued up to I944. Partly this was due to constitutional limitations in the US and bureaucratic rivalries in Britain, but it also expressed the British desire to keep hold of this vital arm of public diplomacy in an era when British global influence was obviously going to decline. The MI's aim to promote British interests gradually gave way to a multilateral IAIC-UNIO apparatus where Britain would hopefully be supported by the Dominions, but the United States, actively building the post-war order through the new UN organisations, was determined to secure its dominant position. The UNIO story therefore illustrates in detail how differing Anglo-American internationalist 
viewpoints competed over the control of wartime information provision, and how this should be seen as another important stage in the transition of global power from London to Washington during the midtwentieth century.

\section{Notes}

I See Kenneth Osgood and Brian Etheridge, 'Introduction', in Osgood and Etheridge (eds), The United States and Public Diplomacy: New Directions in Cultural and International History (Leiden, 20I0) I-25.

2 See for instance Daniel Gorman, International Cooperation in the Early Twentieth Century (London, 2017); Simon Jackson and Alanna O'Malley (eds), The Institution of International Order: From the League of Nations to the United Nations (London, 2018).

3 Foremost in this scholarship is Mark Mazower, Governing the World: The History of an Idea (London, 20I2).

4 See Susan Pedersen, The Guardians: The League of Nations and the Crisis of Empire (Oxford, 2016); Patricia Clavin, Securing the World Economy: The Reinvention of the League of Nations, I920-1946 (Oxford, 2013).

5 This progressive bent has been countered by historians examining the 'dark sides' of international and transnational networks, particularly on the political right. See Jessica Reinisch, 'Introduction: Agents of Internationalism', Contemporary European History 25:2 (2016) 195-205.

6 Micheline Ishay, Internationalism and its Betrayal (Minneapolis, I995) xxi.

7 Glenda Sluga, Internationalism in the Age of Nationalism (Philadelphia, 20I3) 2.

8 One early source, more advocacy than analysis, is Vernon McKenzie, 'United Nations Propaganda in the United States', Public Opinion Quarterly 6 (I942) 35I-66. McKenzie had served as an advisor to the British information campaign during I94I-42. Most studies of the UN begin in 1945, such as Evan Luard, A History of the United Nations (2 Vols., London, I982, I989).

9 Stephen Schlesinger, Act of Creation: The Founding of the United Nations (Boulder, 2003) 53-4. See also an early assessment of the State Department's role in propagating a vision for the post-war world in Wilbur Edel, 'The State Department, the Public and the United Nations Concept, I939-I945', unpublished PhD Dissertation, Columbia University, I95 I. 
Io See Robert Divine, Second Chance: The Triumph of Internationalism in America during World War II (New York, I967); Andrew Johnstone, Dilemmas of Internationalism: The American Association for the United Nations and US Foreign Policy I94I-I948 (Burlington, 2009).

I I Dan Plesch, America, Hitler and the UN (London, 20 I I).

I 2 Sandrine Kott, 'Internationalism in Wartime: Introduction', Journal of Modern European History I 2 (2014) 3I7-22, at 32 I.

I3 Ibid., 320.

I4 Glenda Sluga and Patricia Clavin, 'Rethinking the History of Internationalism', in Sluga and Clavin (eds), Internationalisms: A Twentieth Century History (Cambridge, 2017), I 2.

I5 Jeanne Morefield, Covenants without Swords: Idealist Liberalism and the Spirit of Empire (Princeton, 2005).

I6 Mark Mazower, No Enchanted Palace: The End of Empire and the Ideological Origins of the United Nations (Princeton, 2013); Pedersen, The Guardians.

I7 Elizabeth Borgwardt, A New Deal for the World: America's Vision for Human Rights (Cambridge MA, 2007); Jeffrey Engel (ed.), Four Freedoms: Franklin Roosevelt and the Evolution of an American Idea (Oxford, 20 I 5).

I 8 See Christopher O'Sullivan, FDR and the End of Empire: The Origins of American Power in the Middle East (New York, 2012).

I9 Quoted in Justin Hart, Empire of Ideas: The Origins of Public Diplomacy and the Transformation of US Foreign Policy (Oxford, 20I3), 5I. Notter expressed this opinion during a Division of Cultural Relations meeting in September I94I, three months before Pearl Harbour.

20 Eric Drummond, Ten Years of World Co-Operation (Geneva, I930) 402-3.

2 I Nicholas Cull, Selling War: The British Propaganda Campaign against American 'Neutrality' in World War II (Oxford, I995).

22 Susan Brewer, To Win The Peace: British Propaganda in the United States during World War II (Ithaca, I997) Io.

23 See J.D. Squires, British Propaganda at Home and in the United States I9I4-I9I7 (Cambridge MA, I935); H. Schuyler Foster Jr., 'The Official Propaganda of Great Britain', Public Opinion Quarterly 3 (I939) 263-7I; M.L. Sanders, 'Wellington House and British Propaganda during the First World War', Historical Journal i8 (I975): I I9-46; D.G. Wright, 'The Great War, Government Propaganda and English "Men of Letters" I9I4I9I6', Literature and History 7 (I978) 70-Ioo.

24 Alice Byrne, 'The British Council and Cultural Propaganda in the United States I938-I945', Journal of Transatlantic Studies I I (2013) 249-63. 
25 See Mark Lincoln Chadwin, Warhawks: American Interventionists before Pearl Harbor (Durham, NC, I970), and Thomas Mahl, Desperate Deception: British Covert Operations in the United States, I939-I944 (New York, I998), which both claim extensive manipulation and control by Stephenson's BSC. In contrast, see Andrew Johnstone, Against Immediate Evil: American Internationalists and the Four Freedoms on the Eve of World War II (Ithaca, 20I4), which avoids overplaying British influence in a detailed discussion on key internationalist groups in the United States.

26 On Lothian's importance in Anglo-American relations see David Reynolds, 'Lord Lothian and Anglo-American relations, I939-I940', Transactions of the American Philosophical Society 73 (I983) I-65; Priscilla Roberts, 'Lord Lothian and the Atlantic world', Historian 66 (2004) 97-I27; David Billington Jr, Lothian: Philip Kerr and the Quest for World Order (Westport CT, 2006); Priscilla Roberts (ed.), Lord Lothian and Anglo-American Relations, I900-I940 (Dordrecht, 2009)

27 Minute, T. North Whitehead 'British Publicity in the United States', 6 March I940, A I774/26/45, FO 37I/24227, National Archives, London (hereafter NA).

28 'Need for statements in the United States about current controversies', I6 March I940, A2004/26/45, FO 37I/24228, NA.

29 Cable A2687, Io April I940, FO 371/24228, NA.

30 For details see The Secret History of British Intelligence in the Americas I940-45 (New York, I999).

3I Report on F.R. Cowell (FO) to Angus Fletcher (BLI), I 5 February I940, FO 37I/24227, NA; 'Presentation of the Allied Cause in the United States: use of Czech, Polish, Norwegian and Danish elements', 25 April I940, A3009/26/45, FO 371/24229, NA.

32 Cable A3I 97/26/45, 28 June I940, FO 37I/24229, NA.

33 Cooper to Edward Halifax, 2 July I940, FO 37I/24229, NA.

34 Cable A4025/26/45, I9 September I940, FO 37I/2423 I, NA; T. North Whitehead, 30 October I 940, quoted in Nicolas J. Cull, 'Selling Peace: The Origins, Promotion and Fate of the Anglo-American New Order during the Second World War', Diplomacy \& Statecraft 7 (I996), I-28, at I7; Cable, 7 October I940, FO 37I/2423 I, NA.

35 Huxley to Hull, I6 September I940, and 'Meeting of the Inter-Allied Information Committee', 24 September I940, INFi/435, NA.

36 Mahl, Desperate Deception, 36-7; 'British Publicity in the United States of America', I7 December I940, A5057/26/45, FO 371/26183, NA. 
37 On Berle's importance in this context see Cull, 'Selling Peace', I9; Cull, Selling War, I44-5, I73-5.

38 'Warns Americans of 'Split Loyalties', , New York Times, I I December I94I.

39 Memorandum of Conversation, 9 January I942, and Memorandum, 24 January I942, Diary: January I942, Box 2I3, Adolf A. Berle Papers, Franklin Roosevelt Library, Hyde Park, NY (hereafter AB).

40 'Memorandum re: Registration of Foreign Agents', 5 February I942, Diary: February-March I942, AB; 'The President Vetoes a Bill proposing to restrict Representatives of Friendly Countries in the United States', 9 February 1942, Public Papers of the Presidents of the United States, Franklin D. Roosevelt, 1942 (New York: Harper, I950), 9I.

4I Memorandum, I3 February I942, Diary: February-March I942, AB.

42 'Activities of British Intelligence here', 5 March I942, Diary: FebruaryMarch I942, AB. This meeting involved the British ambassador, Lord Halifax, and the embassy minister Sir Ronald Campbell, the US Attorney General, Francis Biddle, the head of the FBI, J. Edgar Hoover, and Berle.

43 Memorandum, 24 February I942, Diary: February-March I942, AB.

44 Secretary General to the United Nations Information Board, Annual Report I944, Box 6 File I, United Nations Information Organisation (I940-I945), AG-037, UN Archives and Records, New York (hereafter UN).

45 On Eichelberger see Johnstone, Against Immediate Evil.

46 'Minutes of the Sixty-First Meeting of the Inter-Allied Information Committee', 4 November I942, Box 3 File I, UN.

47 'A Tentative Outline of the Development of Policy of the UNI Office since its Inception and some Considerations for Future Development', Annex 2/64 to the Agenda of the 64th Meeting of the UNIB, I I December I942, Box 2 File 2, UN.

48 Cull, Selling War, I93.

49 Arthur Sweetser, 'From the League to the United Nations', Annals of the American Academy of Political and Social Science 246 (1946) 1-8, at 4.

50 'UNIO Direction', 28 August I944, Box 38, Arthur Sweetser papers, Library of Congress.

5I Harold Butler (Washington Embassy) to Kenneth Grubb (MI), 7 April I 944, FO 37 I/40739, NA.

52 These suspicions plagued congressional acceptance of UN involvement in educational and cultural work. See Frank Ninkovich, The Diplomacy of Ideas: US Foreign Policy and Cultural Relations I938-I950 (Cambridge, I98I), 84 . 
53 Townsend Hoopes and Douglas Brinkley, FDR and the Creation of the UN (New Haven, I997), 78, I23-4. Steven Casey's Franklin D. Roosevelt, American Public Opinion, and the War against Nazi Germany (Oxford, 200I) includes only a few references to the United Nations in terms of specific planning for post-war Germany.

54 'Postwar Trends in the United States July Io - July 3 I I943', Box 4 File 7, UN.

55 Secretary General IAIC to IAIC representatives, 5 September I942, Box 2 Miscellaneous, UN.

56 Alan Winkler, The Politics of Propaganda: The Office of War Information I942-I945 (New Haven, I978) 84; Brewer, To Win the Peace, I 5 I-2.

57 R.B. Pugh (Dominions Office) to Campbell Moodie (High Commissioner for Canada), 26 July I 943, WN 20I/5, DO35/I 2 I I, NA.

58 Memo R.B. Pugh, I7 August I943, DO35/I 2 I I, NA.

59 On this point see Francine McKenzie, 'Where was trade at Bretton Woods?' in G. Scott-Smith and J.S. Rofe (eds., Global Perspectives on the Bretton Woods Conference and the Postwar World Order (New York, 20I7), 26380.

60 'The United Nations (December I, I94I - March I, I942)', FCC Quarterly Review, Box 90 File 4, UN; 'Let Us Not Forget: Achievements of the United Nations in I944', Box I I File 8, UN.

6 I 'United Nations and Allied Meetings and Conferences', April I945, Box 85 File 3, UN.

62 'United Nations' Contributions to the War in Europe', n.d. [July I945], Box 85 File 9, UN.

63 'A Tentative Outline of the Development of Policy of the U.N.I. Office since its Inception and Some Considerations for Future Development (Revised)', Annex 3/65a, 65th Meeting, United Nations Information Board, 5 January I945, Box 2 File 2, UN.

64 'Suggested Definition of Policy for the U.N.I. Office (Revised)', Annex 3/65b, 65th Meeting, United Nations Information Board, 5 January I 945 , Box 2 File 2, UN.

65 'Resolution providing for the Formal Constitution of the United Nations Information Organization in the United States of America', March I945, Box 6, Folder: UNIO Annual Reports, UN.

66 On this broader history see G. Scott-Smith, 'The UN and Public Diplomacy: Communicating the Post-National Message', in Dan Plesch and Thomas Weiss (eds), Wartime Origins and the Future United Nations (Abingdon, 20I5), 36-55. 


\section{About the Author}

Giles Scott-Smith holds the Ernst van der Beugel Chair in the Diplomatic History of Transatlantic Relations since World War II at Leiden University, the Netherlands, and in January 2017 became the academic director of the Roosevelt Institute for American Studies. From 20I3-20I6 he was Chair of the Transatlantic Studies Association. His publications include Western Anti-Communism and the Interdoc Network: Cold War Internationale (Palgrave Macmillan, 20I2), Networks of Empire: The U.S. State Department's Foreign Leader Program in the Netherlands, France, and Britain 1950-70 (Peter Lang, 2008), and The Politics of Apolitical Culture: The Congress for Cultural Freedom, the CIA, and Post-war American Hegemony (Routledge, 2002). E-mail: g.scott-smith@ hum.leidenuniv.nl 